IMEJ: Islamic Management and Empowerment Journal

Volume 1, Number 2, Desember 2019. p. $191-204$

P-ISSN:2685-953X; e-ISSN:2686-0317

DOI: 10.18326/imej.v1i2.191-204

website: http://e-journal.iainsalatiga.ac.id/index.php/imej

\title{
Narasi Deradikalisasi Muslimah Bercadar dalam Akun @NiqabSquad_Official
}

\author{
Khoirin Nisai Shalihati ${ }^{1}$ \\ UIN Sunan Kalijaga, Yogyakarta, Indonesia \\ 1irinnisay96@gmail.com
}

\begin{abstract}
The use of veils for Muslim women is still menui pros and cons. The existence of different attitudes is in accordance with the beliefs, values and knowledge of religious beliefs. This study aims to explain the radicalization narratives that have weakened veiled Muslim women by building a more interesting and conceptual comparative narrative, namely, the narrative of de-radicalization. This study uses an ethnographic approach by analyzing the comments column of various parties who argue. The results showed that veiled Muslim women affiliated in @niqabsquad_official were not terrorists, not terrorist wives and not radical Islamists. The @niqabsquad_official account becomes a virtual veiled Muslim group oriented to Mulimah's hijrah concerning obedience to her religion. Each column of comments was filled with opinions and motivations of deradicalization which did not corner a particular religion.
\end{abstract}

Keywords: Deradicalitazion, Muslim Women veiled, Acount @niqabsquad_official

\begin{abstract}
Abstrak
Pemakaian cadar bagi perempuan muslim hingga saat ini masih menui pro dan kontra. Adanya penyikapan yang berbeda tersebut sesuai dengan kepercayaan, nilai-nilai dan pengetahuan agama yang dianut. Penelitian ini bertujuan menjelaskan narasi-narasi radikalisasi yang telah melemahkan kelompok Muslimah bercadar dengan membangun narasi pembanding yang lebih menarik dan konseptual yakni, narasi deradikalisasi. Penelitian ini menggunakan pendekatan etnografi dengan menganalisis pada kolom komentar dari berbagai pihak yang berpendapat. Hasil penelitian menunjukkan bahwa Muslimah bercadar yang berafiliasi di dalam @niqabsquad_official adalah bukan pelaku teroris, bukan istri teroris dan bukan Islam radikal. Akun @ niqabsquad_official menjadi kelompok virtual Muslim bercadar yang berorientasi pada hijrah Mulimah mengenai ketaatan terhadap agamanya. Setiap kolom komentar ramai dipenuhi dengan pendapat dan motivasi deradikalisasi yang tidak menyudutkan satu agama tertentu.
\end{abstract}

Kata Kunci: Deradikalisasi, Muslimah Bercadar, Akun@niqabsquad_official. 


\section{Pendahuluan}

Media virtual memiliki dampak positif maupun negatif bagi kehidupan masyarakat baik secara sosial, pendidikan, kepribadian dan intelektual. Dengan perkembangan extention of ourselves media sebagai sarana diskusi, bertukar informasi, menjalin pertemanan secara cepat, luas dan praktis dapat dilakukan tetapi belum tentu tepat sasaran. Berbagai pendapat mengenai media virtual menjelaskan bahwa batasbatas negara yang awalnya merupakan ruang privasi, tidak lagi menjadi hambatan dalam konsumsi di ruang publik. Sehingga rawan akan benturan konflik meskipun memberikan ruang bagi masyarakat dalam mengetahui lebih cepat mengenai sumber informasi. Karena berbagai tujuan yang tidak lagi paten bahkan terindikasi adanya politisasi, kapitalisasi dan pengalihan isu.

Perkembangan Islam radikal yang dinilai mengalami pertumbuhan setelah terjadinya liberalisasi politik dengan jatuhnya Presiden Soeharto semakin mengalami fragmentasi ke berbagai komunitas keagamaan. Kelompok tersebut dijelaskan untuk mengubah pandangan dunia Muslim Indonesia pada umumnya dengan menerapkan syariah Islam dan pembentukan negara Islam dengan khilafah universal yang ingin diterapkan di Indonesia. Tetapi terdapat fenomena jaringan Islam Liberal muncul sebagai reaksi atas aksi dengan meningkatnya gejala radikalisasi di kelompok Muslim Indonesia. Adanya konotasi Islam Radikal dan Islam Liberal tersebut berbagai narasi konflik dengan memakai aspek keagamaan di Indonesia sangat rawan terjadi. Sehingga dibutuhkan resolusi akan benturan konflik untuk meredam berbagai narasi propaganda keagamaan dalam media yang berkembang dengan jangkauan cepat, luas dan praktis tersebut.

Mythen dkk (2009) menggambarkan penanggulangan terorisme memberikan stigma terhadap komunitas lainnya yang dipandang sama radikalnya dengan pelaku terorisme. Komunitas tersebut biasanya menciptakan stigma tertentu dengan mencari kenyamanan untuk bergabung komunitas yang satu tujuan, visi dan misi. Misalnya, komunitas Muslimah bercadar yang dibentuk karena visi dan misi untuk mewadahi muslimah yang sudah dan atau ingin memakai cadar/niqab. Tetapi seperti pendapat Mythen, stigma negatif cenderung identik terhadap komunitas tersebut seiring dengan isu fenomena radikal yang sedang terjadi.

Begitupun tulisan dari tauhidillah yang mengasumsikan istri teroris 
adalah muslimah bercadar sebagai korban atau anonim yang terlupakan (Tauhidillah, 2009). Dikatakan anonim karena tidak ada kebijakan pemerintah dalam pembinaan, bahkan mengandung stigma buruk dan tidak ada bedanya dengan suami mereka. Padahal tidak semua muslimah yang bercadar merupakan teroris, Islam garis keras dan lain-lain. Stigmastigma tersebut menjadi problematika dalam masyarakat yang mendeskriminasi individu atau kelompok tertentu.

Dengan perkembangan teknologi media yang terjadi, seperti halnya pada tahun 2010 media Instagram mulai menjadi situs jejaring sosial yang diminati di Indonesia. Instagram tidak hanya digunakan oleh individu saja, melainkan dimanfaatkan berbagai kelompok dalam bentuk komunitas untuk mendapatkan public space yang lebih luas dan praktis. Komunitas muslimah bercadar Indonesia memiliki akun Instagram dengan akun @niqabsquad_official. Tetapi dengan berkembangnya isu ekstremisme yang kembali muncul, berbagai pihak menaruh kecurigaan terhadap Islam radikal yang dinilai sebagai sumber konflik. Stigma negatif terhadap individu maupun kelompok keagamaan meningkat sehingga memunculkan gejala ethnic profiling yang meluas. Dengan kecenderungan narasi keagamaan diberbagai media menggiring opini public terhadap muslimah berniqab masuk dalam stigma negatif tersebut.

Akun @niqabsquad_official memberikan narasi keagamaan dengan bahasa yang baik dan penuh kedamaian sebagai himbauan untuk tidak mengencam komunitas muslimah bercadar/niqab sebagai muslimah yang terlibat dalam konflik ekstremisme. Perbedaan stigma yang menggiring kearah justifikasi terhadap kelompok tertentu dinilai akan menimbulkan sebuah konflik (Azra, 2002). Lebih lagi, ketika berbagai perbedaan tersebut dieksplorasi untuk maksud atau kepentingan tertentu dinilai akan menghasilkan konflik yang lebih kompleks. Lewis Coser (1956) mengasumsikan adanya konsep fungsionalisme konflik diasumsikan individu dalam komunitas tersebut akan semakin meningkat solidaritasnya. Begitu pula dalam pendapat Karl Marx menggambarkan adanya konflik jika dalam sudut pandang positif akan menghasilkan masyarakat yang ideal (Ramly, 2000). Dalam teori psikologi menekankan adanya konflik dapat dijadikan sebagai dorongan atau respon yang dapat menurunkan intensitas tindakan agresif akan benturan kontradiksi/konflik yang terjadi (Suciati, 2015).

Berbagai komunitas virtual secara universal yang bersumber dari ajaran Islam memiliki latar belakang budaya lokal yang berbeda, sehingga 
sifat distingtif sering terjadi. Sifat distingtif tersebut menggambarkan pola kebudayaan dan peradaban Islam yang bersifat multi-polar karena Islam dianut oleh individu atau kelompok yang memiliki latar belakang etnis, agama, sosial, budaya, pendidikan dan regional yang beragam. Sehingga adanya wacana peraturan kebijakan pemerintah melarang penggunaan cadar/niqab bagi Muslimah Indonesia dan celana cingkrang bagi Muslim Indonesia dinilai kebijakan yang melanggar Hak Asasi bagi Muslim Indonesia. Dengan adanya wacana pelarangan tersebut, mengakibatkan konsumsi publik baik secara diskusi offline dan online menimbulkan perselisihan dan perdebatan. Dengan berbagai pendapat yang dapat menimbulkan konflik tersebut, komunitas @niqabsquad_official memberikan mediasi dengan narasi keagamaan yang telah dilakukan diberbagai media dan kagiatan baik dalam media offline maupun online. Cara yang dilakukan ini dapat membangun situsi dan kondisi psikis komunitas Muslim tidak terpengaruh dengan wacana yang ada, sehingga propaganda konflik tersebut dapat dihadapi dan rasa toleransi antar umat beragama, suku dan budaya tetap terjaga.

\section{Metode Penelitian}

Penelitian ini menggunakan pendekatan etnografi dengan subyek penelitian komunitas @Niqabsquad_official sebagai salah satu komunitas virtual Muslimah bercadar di Indonesia. Kemudian melakukan pengumpulan data dengan cara analisis wacana melalui kolom caption dan kolom komentar sebagai sumber dan analisis penelitian. Dalam berbagai postingan yang disebarkan, penelitian ini menganalisis postingan pada bulan Oktober dan November 2019. Dengan tambahan studi pustaka sebagai sumber sekunder, seperti literatur pustaka serta jurnal yang berkaitan dengan tema pembahasan. Sehingga validasi data dapat diperkuat untuk mendapatkan data, selanjutnya diproses menjadi hasil tulisan ini.

\section{Hasil dan Pembahasan \\ Teori Kontradiksi}

Johan Galtung dalam merumuskan teori resolusi konflik dengan formula yang terstruktur, dimana sebuah konflik dinilai adanya kontradiksi oleh pihak-pihak yang bertikai. Dengan adanya 
ketidaksesuaian antara sikap dan perilaku memungkinkan terjadi sebuah konflik. Galtung (1973) menekankan What appears impossible may become possible once the concept of reality,. Kontradiksi merupakan sesuatu yang berbeda atau sesuatu yang saling bertentangan. Ketika ruang kontradiksi semakin tegang atau tidak kondusif maka memungkinkan semakin besar konflik yang akan terjadi, demikian pula wujud dari sikap akan bermanifestasi menjadi perilaku.

Galtung menjelaskan konflik dapat dibedakan menjadi dua tipe yaitu konflik struktur dan konflik aktor. Konflik struktur menggambarkan struktur internasional yang membagi negara ke dalam kelas-kelas, yaitu core, semi-periphery, dan periphery. Dalam rangka mencapai kepentingannya, maka relasi yang muncul antara negara core atas negara periphery adalah berupa eksploitasi, penetrasi, dan fragmentasi, contohnya melalui strategi devide et impera. Pada pembahasan tulisan ini difokuskan pada konflik tipe kedua, mengenai konflik aktor.

Konflik aktor yang memiliki perbedaan dengan konflik struktur yang lebih bersifat vertikal dengan kelas-kelas internasional core-periphery, konflik aktor bahkan belum memasuki tahap tersebut, atau lebih tepatnya merupakan konflik internal dalam tubuh aktor/pelaku konflik. Konflik aktor digambarkan sebagai konflik yang terjadi ketika aktor mengalami kesulitan untuk memobilisasi sumber daya yang dimilikinya guna mencapai tujuan, yang mana hal itu membutuhkan kontrol atas internal organisasinya.

Adanya wilayah penerimaan dan wilayah ketidakcocokan memberikan definisi tentang orientasi nilai dan sikap yang bertentangan. Semakin mendalam pengetahuan mengenai faktor dan aspek dari konflik semakin banyak pula dinamika konflik dan cara menemukan win-win solution dalam ranah penyelesaian. Tujuan teori ini adalah menganalisa proses pengambilan keputusan dari persaingan yang berbeda-beda dan melibatkan dua atau lebih aktor atau pelaku dalam konflik.

Bercadar menjadi kebiasaan yang dinilai menjadi masalah yang tidak lagi sederhana, karena stigma publik yang saling bertentangan tersebut menjadi masalah atau kontradiksi. Adanya wacana pelarangan memakai cadar mengakibatkan para Muslimah memperlukan effort lebih dan resisten terhadap wacana tersebut. Sebagai akibatnya, Muslimah bercadar mengalami kesulitan dalam mencari pekerjaan, melakukan aktifitas sehari-hari dan menjalin hubungan sosial agama. Berangkat dari problem tersebut, dibutuhkan dorongan narasi keagamaan untuk 
menjawab kontradiksi dalam ruang publik. Sehingga diharapkan antara sikap dan perilaku tidak akan menimbulkan kontradiksi dalam istilah Galtung tersebut.

\section{Teori Gender}

Kesataraan gender telah diimplementasikan dalam peluang ekonomi, pendidikan, bahkan militer. Dimana konsep dan aplikasi dalam keagamaan membutuhkan peranan gender (Taskaria, 2018). Puspitawati (2012) menjelaskan adanya tanggung jawab dan perilaku yang dibentuk karena tata nilai sosial-budaya dan adat istiadat dari kelompok masyarakat dapat berubah dalam situasi dan kondisi setempat. Dalam konsep gender secara sosial memberikan stigma yang berbeda antara peran laki-laki dan muslimah dalam kehidupan bermasyarakat. Adanya peranan budaya dalam gender telah membedakan peran dan tanggung jawab dimana individu atau kelompok beraktifitas.

\section{Bentuk-bentuk Konflik}

Berbagai konflik mengenai Muslimah bercadar menimbulkan pertanyaan bahkan tidak sedikit penilaian tanpa dasar teoritis dalam bentuk stigma yang memandang seluruh Muslimah bercadar terintimidasi dalam lingkungan yang heterogen (Ratri, 2011). Komunitas @niqabsquad_official merupakan akun komunitas muslimah bercadar di Indonesia dengan 46.1 ribu pengikut dan 1.322 posts (Dilihat pada akun @niqabsquad_official terakhir 17 Desember 2019). Muslimah yang dikenal dengan komunitas yang kritis terhadap situasi dan kondisi sebagai institusi yang dibentuk dari modernisme, ternyata telah mempraktikkan dengan memakai model niqab yang modern/fashionable. Sebagai salah satu usaha mengubah stigma negatif mengenai Muslimah bercadar di dalam pandangan orang lain. Komunitas tersebut memakai mode berpakaian yang lebih kosmopolitan dengan tetap dalam batasbatas moral dan diterima secara etika, sosial dan agama.

Dalam ruang lingkup agama sering menampilkan unsur positifnya, namun terkadang dakwah dengan narasi keagamaan juga menampilkan unsur negatif yang menjadi sumber konflik. Beberapa fenomena konflik menjadi rumit karena menggunakan narasi agama yang dinilai bertentangan antar individu maupun kelompok. Sebagian besar konflik terjadi dikarenakan kajian dakwah atau diskusi ruang publik yang dinilai 
sebagai aspek yang mempengaruhi agama ke ruang lingkup sosial seperti masyarakat dalam dualisme, misalnya, kasus deskriminasi terhadap Muslimah bercadar di Desa To'bia Kabupaten Luwu (Nursalam, 2015). Muslimah bercadar di desa tersebut termarginalkan atau tidak di anggap kelompok masyarakat lain atas keberadaannya. Karena stigma negatif dari masyarakat mengenai cara berpakaian yang berbeda dengan masyarakat pada umumnya dan disamakan dengan penganut aliran sesat yang sedang marak terjadi.

Masyarakat Indonesia secara universal memiliki tingkat rawan akan kekerasan yang cukup tinggi karena secara horizontal dan vertikal dinilai adanya unsur pendukung seperti perbedaan ras, suku, agama dan budaya sosial (Nasikun, 2000). Narasi keagamaan yang terkadang menimbulkan kekhawatiran sebagaian besar komunitas disebabkan karena konflik sering berubah menjadi masalah sosial yang acap kali menimbulkan kekerasan, bahkan terkadang sampai mengakibatkan kekerasan ataupun korban jiwa.

\section{Muslimah dalam Ekstrimisme}

Di Indonesia tidak jarang dijumpai para wanita muslim bercadar. Hal ini karena Indonesia merupakan negara yang penduduknya mayoritas muslim. Muslim di Indonesia banyak menganut faham-faham tertentu sehingga walaupun sesama muslim, mereka akan berbeda apabila menganut paham yang berbeda, baik dalam berbusana maupun cara bergaul mereka di dalam kehidupan sosial (Juliani, 2018).

Penggunaan cadar bagi para perempuan Islam hingga saat ini masih menjadi pro kontra bagi masyarakat Indonesia. Berbagai kalangan masyarakat memiliki pandangan yang berbeda sesuai dengan nilai-nilai, kepercayaan dan norma yang dianut (Cahyaningrum dan Desiningrum, 2017). Pemakaian cadar bukan sekedar cara berbusana, tetapi sebagai bentuk dari ekspresi identitas keagamaan. Hal ini membuat perdebatan tentang pemakaian cadar di kalangan muslim Indonesia dengan perbedaan pemahaman dalam beragama dan sekaligus terkait dengan kesesuaian cara berpakaian . Kontroversi pemakaian cadar ini semakin kuat terkait dengan sering munculnya para perempuan bercadar di media elektronik maupun cetak, baik offline maupun online, setiap kali ada pemberitaan tentang tersangka yang terlibat dalam tindakan terorisme (Rahman dan Syafiq, 2017). 
Pengambilan keputusan oleh Muslimah dalam memakai niqab/cadar mencakup berbagai faktor, seperti kesadaaran diri, pendalaman keagamaan, merubah penilaian seseorang, hijrah penampilan atau tingkat pemahaman. Berbagai faktor tersebut menjadi landasan dalam menjawab justifikasi mengenai Muslimah bercadar yang dinilai terpapar ideology ekstremisme. Misalnya sebagaimana yang dialami oleh Mulimah bercadar dengan inisial Ara dan Jen (Istika, 2018). Keduanya menjadi Muslimah bercadar karena kekagumannya pada Muslimah bercadar lain. Ara mengagumi Muslimah bercadar yang ia jumpai di media sosial karena figur tersebut terlihat begitu anggun dengan pakaian tertutup, jilbab, dan cadarnya.

Sementara itu, Jen mengagumi kakak iparnya (Muslimah bercadar) karena baginya figur tersebut yang mampu memahami permasalahan Jen saat ini karena ia belum mendapat pekerjaan sekaligus nasehat dari kakak ipar yang dinilai Jen religius yang paling menyentuh di hati Jen, terlebih dalam hal fitrah seorang Muslimah wajib dan perlu untuk melindungi tubuhnya (aurat). Melalui momen tersebut, baik Ara maupun Jen kemudian mengimitasi figur-figur tersebut pada tindakan bercadar. Dalam konteks ini perlu diperhatikan pula terkait hal yang dapat menumbuhkan kekaguman itu, yakni pemahaman pada persoalan tersebut. Pemahaman itu dimiliki Ara melalui tahapan internalisasi pengetahuan (intelektual) di sepanjang proses pembelajaran tentang syariat Islam, sementara Jen mendapatkan pemahaman itu melalui pengalaman (eksperiensial).

Dalam laporan IPAC No. 35 membagi empat kelompok ekstremisme muslimah di Indonesia dalam berinteraksi. Pertama, adanya Tenaga Kerja Wanita (TKW) yang bekerja di Asia Timur dan Timur Tengah dengan kemampuan berbahasa,keahlian komputer yang dimiliki mendorong mereka untuk membangun komunitas baru dalam lingkungan baru. Kedua, muslimah Indonesia yang telah bergabung dengan ISIS di Suriah dikarenakan tertarik pada video ISIS tentang negara Islam dan bertekad untuk membesarkan anak-anak mereka dalam hukum Islam sebagai pondasinya. Ketiga, muslimah Indonesia yang dideportasi oleh otoritas Turki karena keinginan mereka menyusul anggota keluarga yang sudah berada di Suriah. Keempat, peran Istri terorisme Poso yang dinilai masih memiliki keterlibatan yang tinggi untuk melibatkan kelompok muslimah dalam pelatihan di masa depan (IPAC, 2017: Report No 35).

Beberapa konflik keagamaan yang viral di media sosial umumnya 
diawali konflik sederhana, kemudian melebar ke konflik yang lebih besar. Misalnya kebijakan pemerintah yang dinilai menyudutkan pihak tertentu, dan ketika pemerintah tidak bisa mengelola konflik tersebut, maka aksi lebih luas melebar ke ranah politik dan ideologis. Dari beberapa contoh konflik di atas, tergambar bahwa narasi keagamaan di media virtual dapat menjadi perekat dan atau ancaman toleransi di Indonesia. Media virtual tesebut menjadi gambaran kondisi negara dan masyarakat, yang menjadi media pembiasan realitas di Indonesia.

\section{Narasi Keagamaan di Media Sosial}

Konflik cenderung muncul sebagai perbedaan antara kelompokkelompok yang menonjol. Perbedaan tersebut mencakup nilai-nilai dan atau norma-norma antara identitas sosial yang menjadi bertentangan (Amiot, 1999). Misalnya pertama, narasi konflik pembakaran masjid di Tolikara (IPAC, 2017: Report No 29). Dalam narasi tersebut pemerintah pusat dan beberapa pemimpin agama Papua dianggap gagal menegakkan kebebasan agama bagi umat Islam di Tolikara, kemudian bergegas melakukan upaya rekonsiliasi tanpa satu kesatuan upaya untuk membangun fakta atau memastikan keadilan. Kedua, kontruksi sosial mengenai muslimah bercadar akan mempengaruhi penilaian masyarakat mengenai kelompok bercadar tersebut antara baik atau buruk, maupun sebagai sahabat atau musuh. Muslimah bercadar mendapatkan identitasnya di tengah masyarakat Muslim sendiri maupun dalam masyarakat plural. Dalam perkembangan narasi keagamaan di Indonesia terdapat berbagai narasi dukungan kelompok tertentu untuk membentuk Islamic State yang dapat meningkatkan resiko kekerasan.

\section{Analisis Konflik: Resolusi Agama di Media Sosial}

Interaksi komunikasi dinilai sebagai isi pesan untuk mencapai tujuan bersama (Wiryanto, 2004). Diharapkan dapat meminimalisir stigma negatif mengenai kehidupan Muslimah berniqab yang dianggap cenderung ekslusif, garis keras, islam fundamental, ataupun isu istri seorang teroris (Ratri, 2011). Stigma-stigma tersebut mejadi kontradiksi bagi Muslimah berniqab yang tidak bermakna sama. Tujuan dari Muslimah berniqab dalam membentuk komunitas yaitu saling 
menguatkan dalam berinteraksi di antara masyarakat umum. Dengan memiliki pemahaman dan sudut pandang akan tujuan yang sama tersebut menjadi cara penyampaian dakwah akan tersampaikan dengan baik.

Dalam proses dakwah yang dilakukan @niqabsquad_official dengan masyarakat melalui narasi-narasi keagamaan maupun kajian yang telah dilakukan akan menentukan apakah @niqabsquad_official berhasil mengatasi konflik ekstremisme pada muslimah bercadar di Indonesia. Menurut Johan Galtung sebuah konflik dinilai tidak simetris karena adanya kontradiksi oleh pihak-pihak yang bertikai. Dengan adanya ketidaksesuaian antara sikap dan perilaku dapat dikatakan akan terjadi konflik. Galtung (1973) menekankan What appears impossible may become possible once the concept of reality. Kontradiksi merupakan sesuatu yang berbeda atau sesuatu yang saling bertentangan. Galtung berasumsi bahwa setiap kontradiksi mengacu pada realitas empiris, tetapi jika terjadi peretentangan masing-masing pihak hanya dapat merujuk pada pengalaman (empirical reality) tersebut dengan negasi adanya realisasi dari semua pihak. Ini artinya konflik dan kontradiksi dinilai dapat terjadi karena adanya celah antara realitas potensial dan realitas empiris.

Fenomena radikalisme Muslimah bercadar pernah menjadi tema diskusi ILC (Indonesia Lawyers Club) pada 5 November 2019 di Tv one, sehingga medsos pun ramai dengan berbagai tanggapan mengenai topik tersebut.

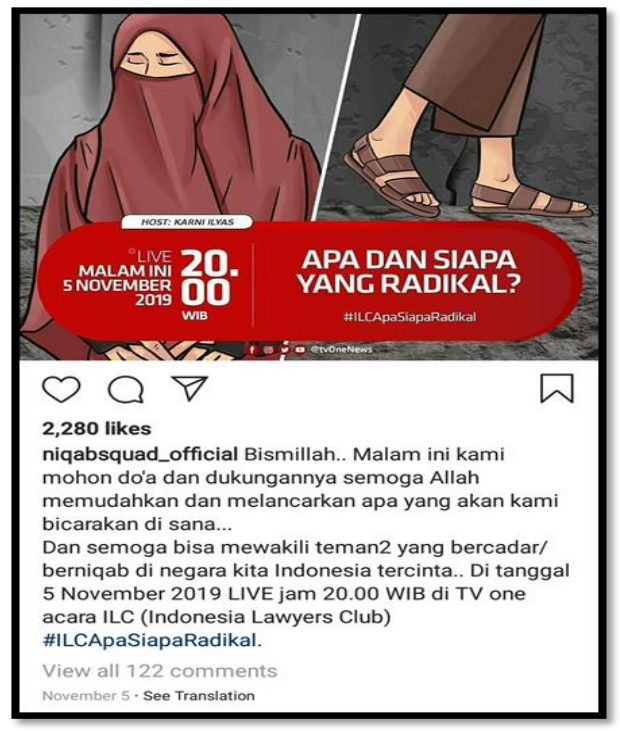

Gambar 1. Postingan akun @niqabsquad_official dengan 2.280 likes dan 122 komentar. Diakses dan screenshot pada 15 Desember 2019. 
Dalam diskusi yang telah dilakukan dalam ruang publik tersebut dapat disebut dengan Intensitying conflict. Intensitying conflict merupakan meningkatnya isu konflik dengan membuat konflik yang latin hiden menjadi konflik yang terbuka dalam ruang pubik (Fisher, 2000). Hal tersebut tidak lepas dari tujuan, agar tidak terjadi meluas dan berlarutnya stigma negatif lingkup sosial sehingga menimbulkan konflik yang lebih besar dalam waktu tertentu. Berbagai stigma setelah diskusi publik tersebut, dalam ruang virtual mendapakan berbagai dukungan.
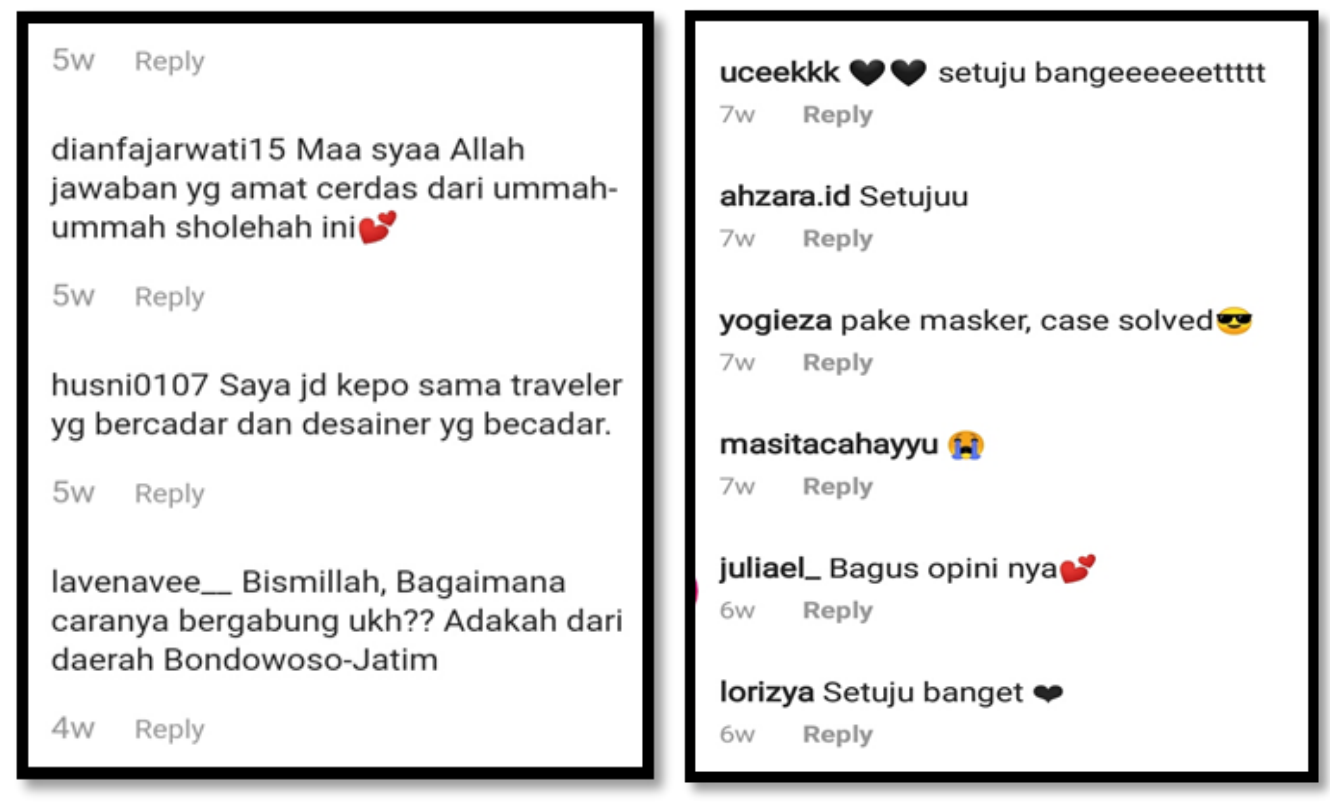

Gambar 2. kolom komentar dalam akun @niqabsquad_official. Diakses dan screenshot pada 15 Desember 2019.

Muncul berbagai persepsi bahwa muslimah bercadar tidak semua menjadi bagian dari isu ekstremis, melainkan melakukan proses hijrah dan mendapatkan dukungan dari berbagai pihak. Banyak aspek yang terkait dengan isu ekstremisme dan telah menguras energi dan waktu pengguna media virtual, namun diprediksi topik pembahasan tersebut meluas karena masing-masing pihak dengan tokoh-tokoh besar di baliknya tetap melakukan perlawanan dengan semangat saling menyerang. Media sosial dapat menjadi kontruktif konflik agama maupun destruktif konflik, dengan memberikan nuanasa yang baru, karena masing-masing pihak berargumen dengan landasan teori yang berbeda.

Bercadar masih menjadi hal yang menakutkan bahkan asing, hal ini 
didukung dari berbagai propaganda yang dikeluarkan media, misalnya istri pelaku teroris, islam garis keras, islam fanatik dan muslimah ekstremis. Dengan menemukan titik tengah, akan menjembatani dialog lintas pemikiran untuk menyelesaikan konflik yang terjadi. Misalnya dengan berdialog dengan komunitas bercadar, menanyakan motivasi dan latar belakang mereka menggunakan cadar. Melakukan dirkursus secara langsung dan mengetahui motivasi komunitas tertentu lebih akan mengetahui tujuan adanya komunitas tersebut.

\section{Kesimpulan}

Sebagai muslimah memiliki peran dominan menjadi aktor damai, lebih besar dari peran laki-laki dalam menyemai kedamaian. Fitrah seorang muslimah memiliki Rahim dan menjaga janin pada diri muslimah, karena sang Esa percaya muslimah lebih mampu menjaga kehidupan. Karenanya, menjadi pelaku dalam ekstremisme bukan pilihan yang sesuai dengan fitrah muslimah.

Keputusan untuk memakai niqab sebagai bentuk simbol hijrah dari masa lalu menjadikan religiusitas berniqab, bukan wujud sebagai Islam radikal, Islam garis keras, ataupun kelompok ekstremisme. Narasi deradikalisasi dalam akun @niqabsquad_official memberikan pengertian sebagai kominitas Muslimah bercadar yang dapat berinteraksi dengan masyarakat dengan profesi yang dimiliki. Dengan demikian, stigma negatif terhadap individu atau kelompok dalam berniqab tidak lagi menjadi fenomena yang akan menimbulkan konflik dalam bingkai diskusi ekstremis dalam media virtual. 


\section{Daftar Pustaka}

Amiot, C.E., Sablonniere, R., Terry, D.J., \& Smith, J. R. (1999). Integration of Social Identities in The Self: Toward a Cognitive-Developmental Model. (Personality and Social Psychology Review. 364-389.

Azra, Azyumardi. (2002). Konflik Baru Antar Peradapan. Jakarta: RajaGrafindo Persada.

Cahyaningrum Retno Dwi dan Desiningrum Ratri Dinie. 2017. Jiwa-Jiwa Tenang Bertabir Iman: Studi Fenomenologi Pada Mahasiswi Bercadar Di Universitas Negeri Umum Kota Yogyakarta. Jurnal Empati, Vol. 7 No. 3. Hal: 278 - 296.

Coser, Lewis. (1956). The Functon of Social Confict. New York: The Free Press.

Galtung, Johan. (1973). Theories of conflict "Definitions, Dimensions, Negations, Formations" University of Hawai'i.

Juliani, Reni. 2018. Stigmatisasi Mahasiswa Tentang Maraknya Mahasiswa Bercadar Di Kampus (Studi Kasus Pada Mahasiswa Fakultas Ilmu Sosial dan Ilmu Politik Universitas Teuku Umar Meulaboh Kabupaten Aceh Barat). Community: Vol. 4, No. 1.

Mythen, Walklate\& Khan. (2009). I'm Muslim, But I'm Not Terrorist: Risk, victimization and negotiation of risky identities. British Jounal of Criminology, 726-756.

Nasikun. (2000). Sistem Sosial Indonesia. Jakarta: Rajawali Press.

Nursalam \& Syarifudin. (2015). Persepsi Masyarakat Tentang Muslimah Bercadar, Jurnal Equilibrium Pendidikan Sosiologi Vol. 3 No. 1 Mei. 116-125.

Puspitawati, H. (2012). Gender dan Keluarga: Konsep dan Realita di Indonesia. Bogor: PT IPB Press.

Rahman, Father Alif. dan Syafiq, Muhammad, 2017. Motivasi, Stigma dan Coping Stigma pada Perempuan Bercadar. Jurnal Psikologi Teori dan Terapan. Vol. 7, No. 2, Hal: 103-115.

Ratri, Lintang. (2011). Cadar, Media, dan Identitas Muslimah Muslim. Jurnal Ilmiah Mahasiswa Universitas Diponegoro, Vol 39, No 2. 10 33.

Ramly, Andi M. (2000). Peta Pemikiran Karl Marx. Yogyakarta: LkiS.

Suciati, (2015). Psikologi Komunikasi Sebuah Tinjauan Teoritis dan Perspektif Islam. Yogyakarta: Buku Litera.

Taskarina, Leebarty. (2018). Muslimah dan Terorisme, Jakarta: PT Elex 
Media Komputindo.

Tauhidillah. (2009). Korban Sebagai Dampak dari Terorisme: Yang Anonim dan Terlupakan. Jurnal Kriminnologi Indonesia, 2009, 1930.

IPAC Report No. 35, Mothers To Bombers: The Evolution Of Indonesian Women Extremists, 31 Januari 2017

No. 29, Rebuilding After Communal Violence: Lessons From Tolikara, Papua, h. 15

No.13, The Evolution of ISIS in Indonesia, 24 September 2014, h. 5 No. 29, Rebuilding After Communal Violence: Lessons From Tolikara, Papua, h. 15.

No.13, The Evolution of ISIS in Indonesia, 24 September 2014, h. 5 No. 56, The Ongoing Problem Of Pro-Isis Cells In Indonesia, 29 April 2019, h. 5

Istika, Nurul. 2018. Tindakan Sosial Dan Religuisitas Muslimah Bercadar (Studi Di Surabaya, Gresik, Dan Lamongan, Provinsi Jawa Timur), Skripsi Fakultas Ilmu Sosial dan Ilmu Politik, Universitas Airlangga. Wiryanto. (2914). Pengantar Ilmu Komunikasi. Jakarta: PT. Grasindo. 